\title{
ГВАТЕМАЛЬЦЫ О СВЕРХЬЕСТЕСТВЕННОМ: РАССКАЗЫ У КОСТРА В АРХЕОЛОГИЧЕСКОЙ ЭКСПЕДИЦИИ
}

\begin{abstract}
Данная работа представляет собой публикацию рассказов о сверхъестественном, зафиксированных автором во время археологической экспедиции в городище Эль-Энканто (департамент Петен, Гватемала) в 2018 г. Во многих археологических экспедициях по всему миру подобную информацию можно усльишать, преимущественно у вечернего костра. Во время раскопок в Эль-Энканто костер располагался в районе кухни и поддерживался круглосуточно, позволяя участникам проекта собираться там каждый вечер для проведения предшествовавшего сну досуга, в том числе делиться так называемыми «рассказами о призраках» (сиеntos de fantasmas). Иногда люди пересказывали сюжеты о иироко известных по всей Латинской Америке персонажах, таких как Льорона, Сомбрерон или Сигуанаба. На этом фоне выделяются те истории, где информанты сами пережили мистический опыт. Делиться подобнылм пережитым опытом для гватемальцев нормально, они не боятся, что их обвинят во люси или посмеются над ними. В роли рассказчиков выступают совершенно разные люди вне зависимости от пола, возраста и образования. Именно такие рассказы представляют наибольшую ценность с точки зрения восприятия сверхъестественного жителями Гватемаль.
\end{abstract}

Ключевые слова: сверхъестественное, Гватемала, археологическая экспедицчия, мистический опыт, призраки

Ссылка при цитировании: Вепрецкий С.В. Гватемальцы о сверхъестественном: рассказы у костра в археологической экспедиции // Вестник антропологии, 2022. № 1. С. 134-149.

DOI: $10.33876 / 2311-0546 / 2022-1 / 134-149$

(C) S.V. Vepretskii

\section{GUATEMALANS ABOUT THE SUPERNATURAL: TALES TOLD AROUND THE CAMPFIRE IN AN ARCHAEOLOGICAL EXPEDITION}

The present work is dedicated to the supernatural stories that the author heard and documented during the archaeological expedition in El Encanto (Petén, Guatemala) in 2018. In expeditions, stories of this kind are usually shared around the campfire. In El Encanto, such a campfire was maintained during the whole

Вепрецкий Сергей Викторович - младший научный сотрудник отдела Америки, Институт этнологии и антропологии РАН (119017, Москва, Ленинский проспект, 32а) и Мезоамериканского центра им. Ю.В. Кнорозова, РГГУ (125047, Москва, Миусская площадь, 6). Эл. почта: servepr@gmail.com; ORCID: https://orcid.org/0000-0003-2550-6799 
night, and the archaeologists could gather around and spend their evenings telling their true-life stories. Among many tales about the well-known supernatural beings, such as La Llorona, Sombrerón, or Sihuanaba, the most important were the ones of the mystical experiences of the storytellers themselves. Regardless of gender, age, or education, completely different people could tell supernatural stories. Sharing such experiences is common for Guatemalans; they are not afraid of being accused of lying or people laughing at them. These stories are of the greatest value for understanding the perception of the supernatural by the people of Guatemala.

Keywords: the supernatural, Guatemala, archaeological expedition, mystical experience, ghosts

For Citation: Vepretskii, S.V. 2022. Guatemalans about the Supernatural: Tales Told Around the Campfire in an Archaeological Expedition. Herald of Anthropology (Vestnik Antropologii) 1: 134-149.

Author Info: Vepretskii, Sergei V. - Junior Researcher, Institute of Ethnology and Anthropology of the Russian Academy of Sciences (Moscow, RF) and Knorozov Mesoamerican Centre, Russian State University for the Humanities (Moscow, RF). E-mail: servepr@gmail.com; ORCID: https://orcid.org/0000-0003-2550-6799.

Вера в сверхъестественное в Гватемале сильна не только среди населения небольших населенных пунктов, но и в крупных городах. Несмотря на то, что официальной религией здесь является католичество, люди, будучи зачастую глубоко верующими, любят рассказывать истории, как общеизвестные, так и основанные на личном опыте, в которых фигурируют персонажи, чьи корни нередко уходят в доиспанскую эпоху. Данная практика в сознании современных гватемальцев не вступает в противоречие с их верой, поскольку упоминаемые сверхъестественные сущности характеризуются, как злые духи, приносящие вред и служащие дьяволу.

Следует отметить, что в Гватемале подобные рассказы очень распространены как часть нормального досуга. Люди не только не стесняются делиться своим опытом соприкосновения со сверхъестественным, но нередко являются инициаторами такого рода бесед. За время, проведенное в этой стране, автор данной работы слышал не менее двух десятков историй, в которых так или иначе присутствовал мистический фактор. Зачастую эти истории, которые сами гватемальцы называют cuentos de fantasmas, «рассказы о призраках», бывают связаны с распространенными во всей Латинской Америке сверхъестественными персонажами, такими как Льорона, Сигуанаба, Сомбрерон и др. Этим объясняется тот факт, что основная канва подобных историй нередко обрастает многочисленными дополнительными деталями. На этом фоне выделяются те рассказы, где вместо общеизвестных призраков и злых духов фигурируют локальные персонажи или явления, которые зачастую просто описываются без указания каких-либо имен. Такие рассказы представляют особую ценность, поскольку в большей степени отражают восприятие сверхъестественного людьми, пережившими подобный опыт.

О сверхъестественных сущностях Гватемалы написано немало работ, представляющих собой как сборники легенд и рассказов, так и научные исследования. Если говорить о сборниках, то в первую очередь следует выделить классическую книгу Мигеля Анхеля Астуриаса «Легенды Гватемалы» (Asturias 1999), впервые опубли- 
кованную в 1930 г. Наиболее известные сюжеты связаны с такими персонажами, как Льорона, Сигуанаба и Сомбрерон. Первая является призраком женщины, которая по легенде убила своих детей, утопив их в реке, после чего она сошла с ума и превратилась в плакальщицу (исп. la llorona). Данный сюжет распространен во всей Латинской Америке, и ему посвящено немало научных статей, где среди прочего авторы пытаются связать Льорону с такими известными прототипами, как Малинче, которая была любовницей Эрнана Кортеса (Johnson 2016), а также осуществляют попытку найти ее доиспанские корни (Rodríguez, Verduzco 2009: 311).

Легенда о Сигуанабе распространена в Латинской Америке не меньше, однако в отличие от Льороны, в разных странах ее могут называть по-разному: в Коста-Рике и Никарагуа она известна, как Сегуа или Сегуанагуа, в Сальвадоре - Сиуэуэт, в Мексике - Матласигуа или Масиуатли, в Гондурасе - Ла Сусья, в Венесуэле - Ла Сайона (Poncela 2000: 44-45). В самой Гватемале она также фигурирует под именем Сигуамонта (Recinos 1916: 50). В зависимости от региона варьируются и детали связанной с ней истории, однако общая канва повествует о том, что данный призрак встречается одиноким путникам на дороге ночью в виде красивой женщины, которая манит их своими чарами на подобии греческой сирены. При приближении к ней у нее обнаруживаются либо копыта, либо голова лошади, что к этому моменту уже не спасает очарованного ей путника от неприятностей, которые могут привести к разным видам смерти. Несмотря на то, что в интернете о ней можно найти большое количество статей на популярных сайтах, в литературе она фигурирует в основном в общих сборниках легенд (Lara Figueroa 1973; Barnoya Gálvez 1990), а сравнительный анализ разных версий этого сюжета проведен в книге Анны Фернандес Понселы (2000: 43-45).

Еще одним популярным персонажем среди гватемальских легенд является Сомбрерон (дословно, «шляпник»), также известный как Цицимите. Его тоже можно охарактеризовать как призрака небольшого роста, который носит огромную шляпу, являющуюся его главным атрибутом. Зачастую ему приписывают и гитару, так как по легенде он поет серенады своим возлюбленным, которым он заплетает косички, а затем крадет их души (Lara Figueroa 1995), поэтому его главными жертвами являются женщины с длинными волосами. В литературе ему посвящено немало работ, среди которых количественно выделяются статьи, посвященные мексиканской версии легенды о Сомбрероне (Equipo de Promotores étnico-culturales 1996; Flores Estada 1998: 39-41; Fuentes 2005: 71-76; La Chica 2016, 2018).

В данной работе основной фокус будет сделан не на конкретном сюжете отдельно взятых региона или этнической группы, а на тех историях, которые автору лично удалось зафиксировать в один короткий отрезок времени, а именно во время пятого полевого сезона проекта «Эпиграфический Атлас Петена», состоявшегося в 2018 г. Данный проект работает в Гватемале с 2013 г. под руководством Д.Д. Беляева и в первую очередь сфокусирован на документации иероглифических надписей древних майя. Пятый полевой сезон был ознаменован тем, что впервые в рамках данного проекта были проведены раскопки, осуществленные на территории городища Эль-Энканто в национальном парке Тикаль (Beliaev, de León 2019).

Быт археологов в полевом сезоне часто располагает к тому, чтобы рассказывать истории из жизни, в том числе делиться опытом о знакомстве со сверхъестественным. Во время раскопок в Эль-Энканто в 2018 г. это было особенно актуально в связи с тем, что на определенное время группа людей, многие из которых ранее не были 
знакомы, оказалась фактически в изолированном пространстве, без связи с внешним миром. Экспедиция базировалась во временном полевом лагере, сооруженном примерно в километре от места раскопок. Не считая трех человек, осуществлявших кратковременные выезды за питьевой водой и провизией, участники проекта не покидали пределов лагеря и места работ.

Рабочий день начинался как правило в восемь часов утра, и длился до четырех часов дня. По возвращении в лагерь у членов проекта было время на отдых до ужина, который подавали в шесть часов вечера. После финального приема пищи все были предоставлены сами себе, не имея при этом большого разнообразия в видах деятельности, и поскольку к семи часам вечера уже темнело, то основным досугом было собраться вместе и поговорить. Следует отметить, что особую атмосферу для рассказов именно о сверхъестественном создавало непрерывное чувство опасности перед агрессивной окружающей средой, изобилующей дикими животными, а также ядовитыми змеями и насекомыми. В таких условиях вечером важную роль играл костер на том месте, где была организована кухня. В подобных экспедициях огонь поддерживается круглосуточно, поскольку на нем происходит весь процесс приготовления пищи, а вечером это самое светлое место в лагере, однако из-за перманентной жары и сильной влажности сидеть возле костра практически невозможно. Тем не менее именно недалеко от костра происходили вечерние беседы.

Данная работа носит скорее ознакомительный характер с «историями о призраках» и рассказами о сверхъестественном, которые можно услышать от разных представителей экспедиции, волей случая оказавшихся в изолированном пространстве полевого лагеря посреди джунглей. Ниже будут приведены несколько сюжетов, которые те или иные члены проекта пережили сами, иногда прямо во время экспедиции. Важно оговориться, что все приведенные ниже тексты являются авторским переводом расшифровок аудио и видео файлов, записанных либо непосредственно в проекте, либо полученных автором от самих информантов в более позднее время. Иными словами, в распоряжении автора нет записей, сделанных непосредственно в момент рассказа. Во всех случаях автор просил информантов повторить тот материал, которым те поделились, сидя у костра. С одной стороны, это придает используемому источнику оттенок вторичности, поскольку на камеру или с диктофоном история может сильно искажаться, с другой стороны, в тех случаях, когда истории пересказывались в более спокойной обстановке и пересылались в виде аудиосообщений, они наполнялись еще большим количеством интересных деталей, о которых при первом рассказе упомянуто не было.

\section{Эль-Энканто и колдуны}

Информант: рабочий из деревни Вашактун (примерный возраст: 50 лет).

Источник: видео файл, записанный на следующий день после первоначального рассказа.

Справка: из всех приведенных текстов, этот больше всего потерял от того, что не был зафиксирован непосредственно в момент рассказа, поскольку много деталей было упущено. Изначальный рассказ был сделан в момент, когда у костра сидела небольшая группа и беседовала на разные темы. Тогда информант просто пришел на кухню, чтобы попить воды, но неожиданно для всех начал объяснять, что мы на- 
ходимся в очень опасном месте, и что с нами уже происходят странные вещи. Среди прочего он объяснил свое понимание названия Эль-Энканто, которое по его версии было дано не просто так, а в связи с мистичностью данного места. На следующий день автор подошел к нему и попросил на камеру повторить то, что было сказано прошедшим вечером, при этом иногда задавая вопросы.

Текст: Называется Эль-Энканто, потому что здесь, как предполагается, было много колдунов в те времена. И они практиковали все виды магии... Или как... Изучали парапсихологию, другими словами колдовство, нет? В общем, это... И по тому, что здесь видно, даже во снах видно, что появляются сверхъестественные вещи. И мы обсуждаем это, так как точно, это... когда... Раньше, когда приходили ребята работать сюда, обратили внимание, что да, было много очарования (исп. encanto). И тогда поэтому они и назвали это место Эль-Энканто.

- И это все, как вы сказали вчера, это все от дьявола?

Да, мы говорим о парапсихологии, или другими словами колдовстве. В общем, действительно, почему нет, здесь это связано с дьяволом. Он был тем, кто манипулировал ими фактически. И они были что-то типа посланников этого, этого демона. Демона, или Сатаны, или Древнего Змея, или Дракона, что одно и то же. Дьявол имеет много имен. И это... Уже несколько дней, как... Я, по прибытии на эти места... Но да, я бывал и в других, но никогда не заходил в такое. Дальше посмотрим, что произойдет. Вот вчера один товарищ рассказал, что видел дуэнде 11 там внизу. Дуэнде.

- Дуэнде это что-то типа ребенка, верно?

- Это демон.

- Да, но выглядит, как ребенок.

- Да, он махонький. Да, маленький.

В общем, это... Через сны, которые ты видишь здесь, тебе показывают, что да, есть много... много парапсихологии на этом месте. Много магий. Черная магия, красная магия, белая магия... Зеленая магия. И более-менее зеленая магия она, чтобы появляться, исчезать и появляться в другом месте. Черная магия, известно, она была для зла. И другие магии развивались. Были и такие, кто даже умел летать. Но они только выглядели, что летают, напоминая ведьму, но на самом деле их носят демоны. Это... Они не видны, так как они духи, нет? Но есть много... Много тайны здесь, что... Вещи, которые как бы, как хотел сказать я, сверхъестественные. Думаю, что на данный момент только это могу сказать.

Комментарий: данный текст показывает, с одной стороны, религиозность сельского населения, а с другой - их веру в повседневность сверхъестественного, которую люди связывают исключительно с дьяволом. Особое внимание хочется уделить классификации разных видов магии, с частичным объяснением, за что каждый вид отвечает. Осталось неясным, откуда информант обладает такими данными, что делает этот вопрос перспективным с точки зрения дальнейших исследований.

\footnotetext{
${ }^{1}$ От исп. duende, что означает сверхъестественное существо маленьких размеров, сродни европейским гоблинам.
} 


\section{Дуэнде на месте раскопок}

Информант: рабочий из деревни Вашактун (возраст: 18 лет).

Источник: видео файл, сделанный через три дня после случившегося с информантом.

Справка: данный текст посвящен истории, случившейся непосредственно во время работы проекта на памятнике, при этом информант был единственным свидетелем произошедшего.

Текст: Хорошо. Где-то примерно два дня назад. Там, где мы делали последний шурф примерно в час дня, это... После перекуса я поднялся и повернулся туда, где были другие раскопы, когда под кустом гуано увидел ребятенка, да? На котором была огромная шляпа, большая. И когда я сказал это дону Эрвину, что там был дуэнде, и он поднялся посмотреть, то тот сразу исчез. Прошел, как будто ветер, и улетел черной тенью.

Комментарий: любопытно, что в тех версиях этой истории, которыми со слов информанта делились другие участники проекта, в ней отсутствовала важная деталь, а именно шляпа огромных размеров. Есть вероятность, что об этом информант решил упомянуть именно на камеру, поскольку, несомненно, хотел намекнуть на связь увиденного им духа с вышеупомянутым Сомбрероном, чьей главной отличительной чертой является именно гигантская шляпа. В тех версиях, которую автор слышал от других участников проекта, говорилось исключительно о призраке ребенка, про шляпу сказано не было.

\section{Тень старика}

Информант: Йованни де ла Крус (возраст: 43 года), участник проекта, отвечавший за безопасность в лагере, поскольку является специалистом по выживанию в джунглях. Информант дал согласие на публикацию своего имени.

Источник: аудиосообщение, записанное 23 марта 2020 г., по просьбе автора.

Справка: история, произошедшая с Йованни, случилась несколько лет назад, и он неоднократно рассказывал ее автору еще до 2018 г., поэтому во время одной из вечерних бесед у костра она снова была пересказана для всех остальных участников проекта. Впоследствии при подготовке данной работы автор попросил Йованни рассказать ее снова, но уже в виде аудиосообщения.

Текст: Привет, Серхио, как дела? Рассказываю. Это было в Чикимуле, в Эскипулаce, на холме, который находится на границе между Гондурасом и Гватемалой. Я был с одним моим другом, так как нам сказали, что на этом холме происходили странные вещи. Что народ там пропадал и все такое. Мы хотели пойти и сделать запись для одной телепрограммы и начали подниматься на холм. Но когда поднялись... У меня хорошая выносливость, я достаточно много могу пройти, но, когда мы пришли на... на вершину этого холма, мы были слишком уставшие. Мы не могли чуть ли не глаза открыть. Мы не поставили даже палатки, только бросили вещи на землю, легли и... и начали видеть что-то типа огоньков между деревьев, но при этом не могли пошевелиться. И мой друг... Я ему ничего не сказал, что были огоньки, и он мне говорит:

- Ты это видишь? - говорит.

И я ему говорю:

- Ты сейчас видишь огоньки? 
И он мне сказал, что да. Мы остались там спать, и на следующий день... Ну ты понял, все это с огоньками было ночью, и на следующий день, когда рассвело, мы начали говорить про эти огоньки, и про то, какими уставшими мы себя чувствовали, и что нам очень не понравилось это чувство усталости. Тогда мы взяли наши вещи и решили спускаться вниз. Разумеется, мы ничего не записали, камеры не включались. Начали спускаться. Когда спустились, я сказал моему другу, чтобы он подождал, так как я хотел пойти пописать. Я подошел к дереву, и когда я писал на дерево, я почувствовал, что как будто большая горсть земли... Мне спину обсыпали землей, и я подумал, что это был мой друг. Я повернулся, чтобы спросить, зачем он обсыпал меня землей, и была ли это шутка. И когда я повернулся, то он стоял как вкопанный, глядя в сторону края леса. Эта область она довольно лесиста. Это все лес. Это холм, про который говорят “зачарованный холм” (cerro encantado), и это лес. И я его спросил, что он видел, так как я видел лишь что-то мимолетное. И он сказал: “Тень. Как будто кто-то сгорбившийся. Он вышел, посмотрел на меня, а потом растворился с ног до головы”.

Он был очень напуган, даже со слезами на глазах. И сказал мне: “Пойдем, пойдем”, а я хотел пойти и заснять то место, где была тень, но он мне сказал, что нет. Мы начали идти, и уже намного быстрее, и по прошествии где-то часа, когда мы уже были в одной из деревушек, вышел один сеньор и спросил нас, что мы там делали. Он сказал нам, чтобы мы не ходили туда, так как там появляется тень старика. Мы ни в один из моментов не говорили ему, что видели тень, и нас раньше никто о ней не предупреждал. Это было что-то случайное то, что мы увидели... Что я и мой друг увидели тень. Мой друг, да, он отчетливо видел тень кого-то сгорбленного и как будто кого-то крупного, и потом она испарилась с ног до головы. И никто нам не говорил, что там были тени или что-то типа этого. Ну и мы не знали, что мы можем найти в том месте. И потом сеньор нам сказал:

- Будьте осторожны, поскольку также там появляются огромные псы с красными глазами.

Но мы сказали:

- Нет, мы уже туда не вернемся, так что эти псы не появятся.

Ведь ощущение усталости было очень-очень сильным.

Комментарий: помимо основной канвы и очень яркого главного персонажа - тени старика - в данном тексте упоминаются немаловажные детали, связанные с гватемальским фольклором, а именно «зачарованные холмы», о которых здесь можно услышать повсеместно (Lara Figueroa 1989: 4-6), а также псы с красными глазами, что можно посчитать отсылкой к одному из известных персонажей гватемальских легенд - Эль-Кадехо ${ }^{1}$.

\section{Разрешение на работу}

Информант: девушка археолог из проекта (возраст: 38 лет).

Источник: аудиосообщение, записанное 23 марта 2020 г., по просьбе автора.

Справка: данный текст, как и последующие два, рассказывает одну из многочисленных историй, случившихся с информантом за время ее полевой работы в

\footnotetext{
${ }^{1}$ По легенде это огромный пес с красными и светящимися глазами, который встречается по ночам одиноким путникам, зачастую не причиняет вреда, а в некоторых случаях даже оберегает ночных путников от неприятностей (Lee 2015: 109-110).
} 
археологических экспедициях. Следует отметить, что при повторном рассказе, информант сообщила намного большее количество деталей, чем упоминалось в той версии, что была озвучена у костра в Эль-Энканто, при этом основная канва не претерпела никаких изменений.

Текст: Ты ведь знаешь, что на памятниках всегда есть разные энергии. Хорошие энергии, плохие энергии, называй как хочешь. Всегда есть. Так как там проживало такое количество народа, верно? И, конечно, умирали тоже многие, так как это жизненный процесс, затрагивающий нас всех. И также много людей были похоронены в своих домах или там, где они проживали. В общем, ты знаешь, что всегда есть энергии, верно? Поэтому всегда, когда я шла на какой-либо памятник, всегда просила разрешение, поскольку среди тех поездок на практику, которые у меня были... Нас было десять археологов, точнее десять, прости, десять студентов археологии и один археолог, который был директором. У нас был проект, где из-за того, что мы не попросили разрешение, из-за того, что были скептичными и из-за много чего еще, с нами произошла очень серьезная ситуация, которую пережила не только я, но мы все в одно и то же время. И директор был вынужден нас собрать вечером и сказать, что пусть каждый верит в то, во что верит, ему все равно, но с завтрашнего дня все мы должны просить разрешение для входа на памятник, а тот, кто не попросит, лучше пусть не выходит работать. Что мы должны были сделать это, поскольку мы все обратили внимание на то, как проходил этот день... На те проявления, затронувшие каждого из нас. Поскольку нас отправляли работать по парам... И в тот день мы были на памятнике, который был где-то 2500-2600 метров над уровнем моря, так как находился на скале, и на горе. И если ты приблизишься, падаешь вниз в пропасть. Вплоть до того, что ты мог умереть, если не смотрел как следует, куда идешь. И было довольно туманно в тот день из-за холода, который всегда поддерживался в воздухе, и потому что был ноябрь, когда мы работали.

В общем, мы все испытали эту ситуацию утром, и, как я и говорю, было туманно, и произошло несколько разных вещей... Когда двигались предметы без всякой причины. Не было никакого ветра, и они двигались вот так, из-за ничего. Одни подруги слышали лошадей, проходящих около них. Мы слышали звуки целого рынка, но поскольку был туман, и мы ничего не видели, то думали, что действительно где-то рядом может быть деревня. И даже директор, верно? Слышал голоса, которые его звали. Кто-то видел двух человек, которые там ходили, но не различил их лиц. Короче... ситуация, которую испытали мы все, думаю, что это я уже сказала. Дело в том, что в тот день мы должны были осуществить картографирование этого... этого памятника. Так как там был археологический памятник, и мы делали карту. И когда мы вернулись домой... Никто никому ничего не сказал о том, что видел. И по возвращении домой каждый попытался сделать карту нашей области. Не выходило ни единой точки, у нас не получалось. Представляешь, мы пробовали типа два-три раза, но нет. И не вышла карта. В общем, когда в итоге все поговорили, и высказали свои ощущения, и директор тоже рассказал, что испытал. Тогда мы и поняли, что надо было просить разрешение у горы, у археологического памятника, у любого природного или культурного места, куда ты идешь. Просить разрешение на то, что ты собираешься сделать исследование, так как ты профессионал и только за этим пришел. Что не собираешься осквернять могилы, что не собираешься ничего там менять. Ведь эти священные памятники - это достаточно деликатная вещь. Вот такой у нас был раз- 
говор. Дело в том, что с тех пор я поняла, что надо просить разрешение. Это я тебе рассказываю про 2001 или 2002 год. И это произошло в Уэуэтенанго, департаменте, который примерно в шести часах езды отсюда, от Гватемалы, от столицы. И произошло это в одной из деревень Уэуэтенанго, где плотно укоренилось то, что... эти памятники... эти памятники - священные. Те горы, где мы ходили, были хранителями года, как их называют, которые должны быть как-то связаны с календарем. В общем, более точная область, где мы были, - это Хакальтенанго, и народ оттуда очень-очень верит в священные памятники и в свои горы, так как для них это их предки.

Комментарий: здесь так же, как и в предыдущей истории от Йованни, фигурируют священные холмы, где происходят «странные вещи», однако в данном случае они не названы зачарованными. При этом информант дает более точную их характеристику, связывающую эти места с календарем майя. Термин «хранитель года» применяется в основном к особым дням священного для майя 260-дневного календарного цикла, которые выпадали на начало солнечного года (Stuart 2004: 1-3). Любопытно, что в сознании местных жителей это привязывалось также к холмам.

\section{Погребение в Вашактуне}

Информант: тот же.

Источник: аудиосообщение, записанное 24 марта 2020 г., по просьбе автора.

Справка: данный текст повествует о ситуации, с которой информант столкнулся лично во время своей работы в Вашактуне, - памятнике, в древности являвшимся одним из крупнейших городов майя. Начиная с 2009 г. и по сей день там ведутся раскопки Словацкого археологического и исторического института под руководством Милана Ковача. В некоторых местах информант делал очень подробные археологические описания, которые автор счел нужным не вставлять, поскольку они никак не влияют на саму историю.

Текст: Короче, ты знаешь, что в Вашактун меня наняли как руководителя раскопок, археолога-копателя, называй, как хочешь, полевого археолога. И мы отправились в Вашактун. Короче, нас разделили по разным группам и меня отправили в Группу С. Я отвечала, как я уже сказала, знаешь, исключительно за раскопки, и была еще одна словачка. Анна, по-моему, ее звали, но фамилию не помню. Она тоже была там в Группе С, и она решила копать более высокие здания. В группе было несколько конструкций, не помню, типа десять в общей сложности, на той части платформы, так как это небольшой... Если ты замечал, когда был в Вашактуне, там небольшие холмы или островки, если можно так сказать, которые имеют естественную возвышенность, и их использовали, чтобы строить в высоких местах. В общем в эту Группу С нужно было подниматься прилично, что было довольно утомительно, так как возвышенность была довольно высокая. И там наверху были конструкции, где уже можно было копать. До того, как туда подняться, то, что... Это... кладбище было рядом с этой Группой С. Там есть дорожка к группе А, которую ты уже знаешь, но только вместо того, чтобы свернуть налево, где группа А, кладбище было слева13. И рядом с кладбищем была небольшая группа, где мы и были. <...>

\footnotetext{
${ }^{1}$ Вероятнее всего, здесь оговорка, и имелось в виду справа.
} 
В общем меня отправили в ту зону, как я и говорю, и по прибытии содиректор проекта ${ }^{1}$ мне сказал:

- Видишь эти крупные конструкции, их хочет копать Анна.

- Хорошо, оставьте ей большие - сказала я, - мне что ни копай, я буду копать маленькие.

И была одна конструкция, так сказать, которая возвышалась где-то на 40 сантиметров над поверхностью. И он сказал мне:

- Смотри, вот эти вытянутые выглядят интересно. Если хочешь, давай.

- Ладно, - говорю, - возьму вот эту, чтобы начать и посмотреть, какой была эта конструкция.

Она выглядела достаточно длинной и пропорциональной, так сказать. И та, которую копала Анна, словачка, была большой, типа где-то 7 метров в высоту, возможно. В общем, да, была большая разница, верно? И мне всегда нравилось копать что-то маленькое, или то, что выходит за рамки элиты или могущества, так сказать, но это было немного нелогично, поскольку ты знаешь, что находишься в группе, где точно жила элита, верно? Потому что это такое место. Но все равно мне больше хотелось копать маленькую конструкцию. Ладно. Короче, когда я начала <..> когда я начала раскопки, ну да, я попросила разрешение, сказала, что я прибыла сюда исследовать. Мысленно, верно? Разрешение и та та та. И мы начали раскоп. Мне дали двух рабочих, которые были двумя братьями из деревни Вашактун. И помимо них... Один был копателем, а другой помощник. И помимо них еще один копатель дон Маркос, который тоже из этой деревни. И братья... Одного звали Габриэль, и другого... Мануэль (не помню, Мануэль или Мигель, по-моему, Мануэль). Короче, были они трое там, и мне помогали в раскопках, и тут... эээ... Когда я спустилась пообедать... Поскольку я всегда спускалась обедать в лагерь, так как моя группа была где-то в 35 минутах пешком от лагеря, где была Сильвия, керамист, где были все наши палатки, где вы уже бывали, в тот раз, когда мы приезжали в Вашактун. Ладно, я вернулась пообедать, и в этот момент Сильвия мне сказала:

- Как дела? - сказала.

- Да хорошо - говорю.

- Нашла что-нибудь - говорит, - там наверху или что?

- Нет, - говорю, - не хочу ничего находить, что бы ни было, так как ты знаешь, что мне не нравится находить погребения, мне не нравится.

- Не зацикливайся на этом - говорит, - и все.

И до того, как произошел этот разговор... Это я тебе рассказываю про апрель, так как была одна неделя до Семаны Санты². И нам сказали, что “если вы найдете погребение за неделю до Семаны Санты, вы не уезжаете, вы остаетесь”. Так как нам собирались дать несколько дней, чтобы съездить отдохнуть во Флорес. "Вы останетесь, - нам сказали, - так как вы должны будете разобрать погребение и расчистить все”. И Сильвия, и все остальные сказали: “Вот ведь... нет, никто не хочет ничего находить”. Так как мы знаем, как непросто с погребениями, и необходимо два-три дня, так что даже можно остаться там ночевать. Мы начали говорить разные вещи, так как все зависит от погребения и от времени, которое тебе дано, верно? Но обычно у тебя уходит

\footnotetext{
${ }^{1}$ По просьбе информанта автор не стал раскрывать имя содиректора проекта.

${ }^{2}$ Святая Неделя - в Гватемале период каникул, включающий в себя одну неделю до Пасхи и одну неделю после.
} 
не меньше одного или двух дней, чтобы разобрать его, так как бывает очень много деталей... Каждая вещь, которую ты находишь. Короче... Я сказала: “вот ведь... я не хочу ничего находить, я хочу уехать в эти дни, так как все вокруг уедут. Я хочу поехать во Флорес отдохнуть". Короче, это были лишь мысли. Я вернулась, и когда мы... В тот конкретный день мы спокойно копали, а на следующий день пришли утречком, когда... До того, как произошло это, было солнце, и прям жарило. Сильно, сильно, поскольку в такие дни довольно сильное солнце, там все сухо кругом. Внезапно раз, налетели облака, и начался дождь. “Вот ведь блин, - сказала я, - почему идет дождь? Так странно”. И он шел без преувеличения пять минут, не больше, пять минут. Был ливень, да, очень мощный, и вдруг резко все прекратилось, и опять солнце, также сильно-сильно. И я такая: “Вот ведь... Ладно, продолжаем, да?”, - говорю рабочим. И тогда один мне говорит: “Сеньо ${ }^{1}$, здесь какая-то плита”. "Вот ведь черт, эти плиты. Нет”, - говорила я. Ты ведь знаешь, что есть некоторые указатели на то, что есть погребение. "Не хочу, не хочу начинать, - со всем негативом, - не хочу!”. “Ладно, - сказала я, - не важно”. И тогда почти уже было время уходить. Короче... Мы прикрыли там, и я вернулась в лагерь. Тогда я сказала Сильвии: “Ай, мне кажется, что там погребение сказала я, - я не хочу”. И Сильвия просто на меня смотрела, а потом сказала:

- Я поэтому тебя спрашивала. Во время обеда вчера, по-моему. Нашла ли ты чего или нет.

- Почему? - сказала я.

- Знаешь, не хочу тебя пугать - сказала, - лучше давай, давай продолжай все это. Завтра надо все сделать, так как смотри, неделя осталась. Если нет, то ты останешься тут.

- Вот ведь... - сказала я, - не хочу, не хочу оставаться тут.

- Ладно, давай, продолжай. Выкидывай все это из головы, хватит быть негативной, так как надо это сделать. Думать, как профессионал, и сделать все.

В общем, мы вернулись, верно? То есть, прошел этот день, и вернулись. И начали копать. И сказано - сделано, верно? Там было погребение. И было на самом деле очень... очень пропорциональным. < ..> И когда мы его открыли, там были все подношения хорошей сохранности. Не очень хорошо сохранились его кости, так как часть была повреждена корнями, и они были немного изменены. В то время в проекте был фотограф Артуро, который помогал все документировать. И Артуро пришел и начал все готовить к съемке, верно? Мы не могли копать, ни чего-либо еще делать, так как ему нужно было сделать фотографии всего в контексте, непотревоженным. $<$...> Короче, он начал снимать и сказал:

- Мне нужно не больше пяти минут, так как погребение очень качественное, все чисто и сделано хорошо.

- Хорошо, - сказала я, - у тебя столько времени, сколько потребуется, нет проблем.

И началось: 5 минут, 10, 15, полчаса. Я: “Когда он закончит? Мне надо продолжать”. Ведь я хотела разобрать его и все, так как я не хотела оставаться там. Почему он не торопится? Уже прошло 40 минут или час, и потом он мне сказал: “'Знаешь, я лучше оставлю все так, - только это сказал, - лучше оставлю как есть, поскольку никак не могу выбрать правильный угол”. И я видела, что он пробовал, убирал свет, ставил его, садился, вставал. Сделал много чего. “Ладно, - сказала я, - не вышла какая-то фотография, или что там происходит”, - сказала я, но не обратила на это внимания.

${ }^{1}$ В Гватемале зачастую слова señora и señorita сокращаются до просторечного seño при обращении. 
До этого, прости, когда еще нашли плиты, в этот самый момент я послала одного из ребят, не знаю, был ли это Мануэль или Габриэль, в деревню, чтобы он пошел и купил мне в магазине свечей. Идея была в том, чтобы поставить одну свечку, так как мы собирались открыть погребение, и я хотела попросить разрешение, чтобы его открыть. И я попросила разрешение. Я сказала, чтобы нас простили, что это все для научного исследования, и что я бы все оставила как есть, проекту нужно было разобрать его, чтобы изучить. Я говорила в этом духе, верно? Короче, я зажгла свечку и всегда держала ее там. В общем, в тот день с фотографиями Артуро он меня спросил: "У тебя тут свечи? Как хорошо, что они тут есть. Это хорошо”. В общем, он после часа или часа с четвертью, помню, ушел. Но я не увидела, как бы, на его лице удовлетворения от сделанных фотографий, верно? Сейчас помню, что я сказала. "Не переживай - сказала ему я, - в любом случае, если не вышла какая-то, у меня есть мои собственные фотографии, и там видно хорошо”. “А, хорошо”, - сказал он и ушел. В общем, когда все расчистили, вынули все сосуды, в ту ночь мне сказала Сильвия:

- Ладно, ты уже все разобрала, все расчистила, теперь я могу сказать, что мне приснилось.

- Что тебе приснилось?

- Ты помнишь, когда пошел дождь, такой сильный, но при этом всего на пять минут?

- Да.

- Я знала, что ты что-то нашла, и что это была именно ты.

- Черт, почему?

- Это все из-за того, что ты не хотела, не хотела ничего находить. И этим ты все призвала - сказала она, - вызвала в своих мыслях. Тем, что не хотела, этим и вызвала, и тебе это сразу было дано. Поэтому никому не нужно быть негативным. Тебе нужно учиться быть более позитивной.

- Хорошо, значит это был мой первый урок. И что же тебе приснилось?

- Представляешь, да, меня ужаснуло то, что ты нашла. То, что ты нашла этого мальчика.

- Мальчика?

- Да, мальчика.

- И откуда ты знаешь это?

- Представляешь, я видела, как он умер, и в этом не было ничего хорошего. Это было сделано очень жестоко, очень грубо и с очень сильной болью.

Я в этот момент почувствовала такую тяжесть на плечах, что не могу тебе даже объяснить. Такую грусть, не знаю, от тяжести того, что она мне рассказывала.

- И этот сон я видела до того, как пошел дождь. Когда ты пришла обедать, и я увидела беспокойство на твоем лице, что там что-то могло быть, я сразу поняла, что это была именно ты. - Сказала она.

- Когда шел дождь - сказала я, - я как раз и нашла погребение.

Это было первое, о чем подумала Сильвия, представляешь. И в тот же день или вечер меня позвал Артуро. Он выгружал все фотографии, которые сделал. И говорит мне:

- Смотри, не знаю, что произошло... Я делал и делал фотографии, и у меня ни одна не выходила, не могу поверить. Я сделал где-то пятьсот фотографий, не вру, смотри, вот они. Вышли расфокусированные, поврежденные, огромное количество 
фотографий просмотрел, и только где-то пять вышли относительно хорошо, но и здесь я не очень удовлетворен, так как могло бы быть намного лучше.

- Ты не переживай - сказала я, - у меня есть мои фотографии, и на моих все видно неплохо. Это не такой профессиональный фотоаппарат, как у тебя, но все равно видно хорошо.

- Я не понимаю, что произошло. Это очень странно все это. Не могу поверить. Я ставил свет, убирал его...

- Да, да, я тебя видела - сказала я.

- Это первый раз, когда такое случается - сказал он, - но ладно, теперь знаем, что всегда случается что-то странное.

- Не переживай.

И так все и осталось.

Комментарий: Эта довольно длинная история красноречиво показывает не просто отношение археолога к чему-то сверхъестественному, но и повествует об их взаимоотношениях с раскапываемым местом. Несколько раз в тексте упоминалось то, что было главной идеей предыдущей истории, а именно необходимость попросить разрешение на работы у духов, или у кого-то, кто отвечает за те или иные места, иначе тебе просто не дадут нормально работать.

\section{Второе погребение в Вашактуне}

Информант: тот же.

Источник: аудиосообщение, записанное 24 марта 2020 г., по просьбе автора.

Справка: данный текст является непосредственным продолжением предыдущего, но поскольку характер описываемых событий здесь несколько иной, автором было решено выделить это в отдельную и самостоятельную историю.

Текст: Да, я смогла уехать на Семану Санту, что было ровно тем, чего я хотела. Не помню на два или на три дня, не помню. Дело в том, что мы вернулись копать, думаю, что уже в другом месяце, уже не помню. И где-то через 40 сантиметров, или 30 сантиметров, не больше. Мы копали, и один рабочий мне сказал... И до того, как он мне сказал, началось все снова, такая же ситуация: тучи, много ветра. Но в этот раз было иначе, понимаешь. Не было такого сильного дождя, скорее такой легкий, скорее больше ветра, и вскоре раз, и все прошло. И он сказал мне: "Посмотрите, Сеньо, тут еще одно! То, что Вы так не хотели, появилось еще одно”. "Вот ведь черт - сказала я, - еще одно погребение, не может быть. Что происходит?”. Но ладно. Тогда я уже немного сбросила негатив, который был с первым погребением, и решила относиться к этому позитивнее, как мне и говорила Сильвия. В общем, мы начали копать, верно? Но, как я уже говорила, это была довольно разрушенная конструкция и на самом деле там не было места, чтобы копать так же, в этом втором погребении. В первом да, было все свободно, поскольку оно было на одном из слоев пола. Под одним из слоев пола, прости. Между седьмым и восьмым полом было другое, но уже под скамьей. Была также скамья. В общем, эта конструкция была полным месивом. Маленькая, но давшая столько деталей. Короче, начали копать, верно? Я также поставила свечи и все такое. Короче, повторюсь, место было очень узким, и я решила поставить... Решила попросить Мануэля (поскольку Габриэль вытаскивал землю снизу, а дон Маркос копал угол конструкции в другом месте)... Было где-то час дня, 
и я сказала: “Мануэль, положите камень рядом с черепом, так как мне ноге не удобно, уже затекла, но мне еще нужно все зарисовать и замерить. Помогите мне”. В общем, это было где-то в час дня, и солнце мне жарило в спину, а он оставался спереди. Короче, когда я решаю спустить мою ногу, я не заметила, я не смотрела вниз, просто решила спустить ногу и нащупать камень, я почувствовала, что ногу схватила рука, вот так, раз! Я это почувствовала на той части, как бы сказать, за коленкой, чуть ниже, но сзади. Почувствовала руку, все пять пальцев, но при этом не испытала страха. Могу тебе сказать, нисколечко не было страха, никакой дрожи, только единственное, что как будто что-то мимолетное пришло мне в голову и сказало: “Уважай меня!”. Вот так было. Прямиком в мозг эти слова: “Уважай меня!”. И я поняла, кто меня просит, чтобы я его уважала, поскольку на самом деле я наступила на его череп. Когда я посмотрела вниз, да, мой ботинок наступил на череп, не на камень. И в тот же момент, хотя я не чувствовала страх, было немного напряжно, так сказать. И то, что меня напрягло... Солнце светило на меня сзади, и я видела только тень от деревьев напротив. На лице Мануэля, на полу и во всем раскопе. И тут я увидела, как какая-то другая тень проскользнула мимо. Прямо перед Мануэлем. В общем, когда я увидела лицо Мануэля, он вообще довольно светлый, но все равно он был еще более бледный, чем обычно. И я с лицом, которое тоже, думаю, было очень бледным из-за проскочившей тени и из-за руки, которую я почувствовала на ноге. Я его спросила:

- Вы это видели?

- Сеньо, лучше давайте продолжим работать. Лучше не будем обращать на это внимания. Давайте рассказывать добрые истории, не знаю, шутки хочу услышать. Он вот так начал говорить из-за нервозности.

И мы оба это испытали, и было довольно жестко, но в основном это были чувства уважения, не страха. Не то, чтобы это в нас вселило страх, скорее уважение к тому, кто был внизу, так как мы по факту выкапывали его тело. В общем, тогда я поняла и научилась, что на самом деле лучше всегда соблюдать все предосторожности, спрашивать разрешение, работать наиболее уважительно, когда находишь такого рода вещи.

Комментарий: здесь также красной нитью проходит идея уважения к тому месту, где ты работаешь, но в отличие от предыдущих археологических историй, здесь происходит непосредственный контакт между информантом и сверхъестественным. Причем контакт как физический - через прикосновение, так и вербальный - через слова «Уважай меня», которые информант поняла, но не услышала.

В заключении следует отметить, что приведенные тексты, несмотря на их небольшое количество, могут быть полезными для характеристики отношения гватемальцев к сверхъестественному. Информанты, будучи совершенно разными представителями гватемальского общества, отличаясь с точки зрения как образования, так и религиозности, имеют схожее восприятие сверхъестественных событий, которые им пришлось пережить. Следует также выделить особое отношение к окружающему миру, в котором всегда находится место для чего-то сакрального, священного и потустороннего, что при этом вызывает у них глубокое уважение, будь то гора, археологический памятник или древний дух. Несмотря на довольно узкий фокус, публикуемые тексты видятся перспективными для более глубокого изучения и проведения сравнительного анализа со схожими сюжетами, что должно значительно улучшить разработку данной тематики. 


\section{Источники и материалы}

Asturias 1989 - Asturias M. A. Leyendas de Guatemala. Edición de Alejandro Lanoël. Madrid: Cátedra, 1999.

Barnoya Gálvez 1990 - Barnoya Gálvez F. Cuentos y leyendas de Guatemala. Guatemala: Piedra Santa, 1990.

Lara Figueroa 1973 - Lara Figueroa C.A. Leyendas y casos de la tradición oral de la ciudad de Guatemala. Guatemala: Editorial Universitaria, 1973.

Lara Figueroa 1989 - Lara Figueroa C.A. Leyendas de encantamientos y Señores de los cerros // La Tradición Popular, 1989. № 73. P. 1-17.

Lara Figueroa 1995 - Lara Figueroa C.A. Por los viejos barrios de la ciudad de Guatemala. Guatemala: Ediciones Artemis y Edinter, 1995.

\section{Научная литература}

Beliaev D.D., de León M. (eds.) Reconocimiento del Sitio Arqueológico El Encanto. Informe Final, Primera Temporada de Campo 2018, Proyecto Atlas Epigráfico de Petén. Nueva Guatemala de la Asunción, Guatemala, 2019. DOI:10.13140/RG.2.2.12301.90082 https://www.researchgate.net/publication/340595388_Proyecto_Atlas_Epigrafico_de_Peten_Informe_Final_Primera_Temporada_de_Campo_2018_Reconocimiento_del_Sitio_Arqueologico_El_Encanto

Equipo de Promotores étnico-culturales. Cómo surgió El Sombrerón // Cuentos que parecen historia, historias que parecen leyenda. Ciudad de México: Praxis, 1996. P. 72-73.

Flores Estada F. Algunas leyendas coletas y de Chiapas. San Cristóbal de las Casas: Talleres de Editorial y Publicidad Flores, 1998.

Fuentes R. J. Cuentos chiapanecos de terror urbano. Relatos y leyendas. Tuxtla Gutiérrez: Ediciones y Sistemas Especiales, 2005. P. 71-76.

Johnson L.C. La Llorona and La Malinche in Re-Vision: Chicana Poets Countering Traditions and Claiming Voice // Women Versed in Myth: Essays on Modern Poets / C.S. Harris and V.E. Frankel (eds.). McFarland, 2016, P. 140-47.

La Chica M. C. El Sombrerón. Una visión literaria del 'otro' en la tradición oral tojolabal // Los personajes en formas narrativas de la literatura de tradición oral de México / C.C. Vera y M. Zavala (eds.). San Luis Potosí: El Colegio de San Luis, 2016. P. 383-408.

https://www.researchgate.net/publication/303933682_El_Sombreron_una_vision_literaria_del_ otro_en_la tradicion_oral tojolabal

La Chica $\bar{M}$. $\bar{C}$. Sombrerón y la mula: el viaje al otro mundo en un relato maya tojolabal // 'Irás y no volverás’. El viaje en formas narrativas de la literatura tradicional de México / C.C. Vera, N.D. López Torres y M. Zavala (eds.). San Luis Potosí: El Colegio de San Luis, 2018. P. 345-376.

Lee D. La recuperación de la identidad en "Leyenda del Cadejo", de Miguel Ángel Asturias // Sincronía. 2015. Vol. XIX, № 68. P. 107-121.

http://sincronia.cucsh.udg.mx/pdf/68/lee_68.pdf

Poncela A. F. Protagonismo femenino en cuentos y leyendas de México y Centroamérica. Madrid: Narcea Ediciones, 2000.

Recinos A. Algunas Observaciones Sobre el Folk-Lore de Guatemala // The Journal of American Folklore. 1916. Vol. 29, № 114. P. 559-566.

Rodríguez S., Verduzco G. La Llorona: Análisis literario-simbólico // Ensayos sobre ciencia ficción y literatura fantástica: actas del Primer Congreso Internacional de literatura fantástica y ciencia ficción (1, 2008, Madrid) / T.L. Pellisa y F.A. Moreno Serrano (eds.). Madrid: Asociación Cultural Xatafi: Universidad Carlos III de Madrid, 2009. P. 306-318. https://www.researchgate.net/ publication/316630236_La_Llorona_analisis_literario-simbolico

Stuart D. New Year Records in Classic Maya Inscriptions // The PARI Journal. 2004. Vol. 5, № 2. P. 1-6. http://www.mesoweb.com/pari/publications/journal/502/NewYear.pdf 


\section{References}

Beliaev, D.D., de León M. (eds.). 2019. Reconocimiento del Sitio Arqueológico El Encanto [The Reconnaissance of the Archaeological Site of El Encanto]. Informe Final, Primera Temporada de Campo 2018, Proyecto Atlas Epigráfico de Petén [The Final Report, the First Field Season in 2018, Atlas Epigrafico de Peten Project]. Nueva Guatemala de la Asunción, Guatemala. DOI:10.13140/RG.2.2.12301.90082

https://www.researchgate.net/publication/340595388_Proyecto_Atlas_Epigrafico_de_Peten_ Informe_Final_Primera_Temporada_de_Campo_2018_Reconocimiento_del_Sitio_ Arqueologico_El_Encanto

Equipo de Promotores étnico-culturales. 1996. Cómo surgió El Sombrerón [How Did El Sombrerón Arise]. Cuentos que parecen historia, historias que parecen leyenda [Tales that Seem Like History, Stories that Seem Like Legend], 72-73. Ciudad de México: Praxis.

Flores Estada, F. 1998. Algunas leyendas coletas y de Chiapas [Some Braided Legends of Chiapas]. San Cristóbal de las Casas: Talleres de Editorial y Publicidad Flores.

Fuentes, R. J. 2005. Cuentos chiapanecos de terror urbano. Relatos y leyendas [The Chiapas Stories of the Urban Terror. Tales and Legends]. Tuxtla Gutiérrez: Ediciones y Sistemas Especiales.

Johnson, L.C. 2016. La Llorona and La Malinche in Re-Vision: Chicana Poets Countering Traditions and Claiming Voice. Women Versed in Myth: Essays on Modern Poets, edited by C.S. Harris and V.E. Frankel, 140-147. McFarland.

La Chica, M. C. 2016. El Sombrerón. Una visión literaria del 'otro' en la tradición oral tojolabal [El Sombreron. A Literary Vision of the 'Other' in the Tojolabal Oral Tradition]. Los personajes en formas narrativas de la literatura de tradición oral de México [The Characters in Narrative Forms of the Mexican Oral Tradition Literature], edited by C.C. Vera y M. Zavala, 383-408. San Luis Potosí: El Colegio de San Luis. https://www.researchgate.net/publication/303933682 El_Sombreron_una_vision_literaria_del_otro_en_la_tradicion_oral_tojolabal

La Chica, M. C. 2018. Sombrerón y la mula: el viaje al otro mundo en un relato maya tojolabal [Sombrerón and the Mule: the Trip to the Other World in a Tojolaba Mayan Story]. 'Irás y no volverás'. El viaje en formas narrativas de la literatura tradicional de México ['You Will Go and You Will Not Return.' The Journey in Narrative Forms of the Traditional Literature of Mexico], edited by C.C. Vera, N.D. López Torres y M. Zavala, 345-376. San Luis Potosí: El Colegio de San Luis.

Lee, D. 2015. La recuperación de la identidad en "Leyenda del Cadejo", de Miguel Ángel Asturias [The Recovery of Identity in "Leyenda del Cadejo", by Miguel Ángel Asturias]. Sincronía XIX (68): 107-121. http://sincronia.cucsh.udg.mx/pdf/68/lee_68.pdf

Poncela, A. F. 2000. Protagonismo femenino en cuentos y leyendas de México y Centroamérica [Female Protagonism in Tales and Legends of Mexico and Central America]. Madrid: Narcea Ediciones.

Recinos, A. 1916. Algunas Observaciones Sobre el Folk-Lore de Guatemala [Some Observations on the Folk-Lore of Guatemala]. The Journal of American Folklore 29 (114): 559-566.

Rodríguez, S., Verduzco, G. 2009. La Llorona: Análisis literario-simbólico [La Llorona: Literarysymbolic analysis]. Ensayos sobre ciencia ficción y literatura fantástica: actas del Primer Congreso Internacional de literatura fantástica y ciencia ficción (1, 2008, Madrid) [Essays on Science Fiction and Fantasy Literature: Proceedings of the First International Congress of Fantasy Literature and Science Fiction (1, 2008, Madrid)], edited by T.L. Pellisa y F.A. Moreno Serrano, 306-318. Madrid: Asociación Cultural Xatafi: Universidad Carlos III de Madrid, 2009.

Stuart, D. 2004. New Year Records in Classic Maya Inscriptions. The PARI Journal 5 (2): 1-6. http://www.mesoweb.com/pari/publications/journal/502/NewYear.pdf 